\title{
NIGHTS OF CABIRIA
}

Not the smooth Italy of darks and falling,

Not a white lake holding its proper moon.

He throws her, in the sunlight, in the sewer Outside the Amoco refinery.

He tucks her cloth purse quickly in his trousers.

He runs off through the temporary housing.

Glandular adolescents fish her out.

She stinks; they save her,

Pump her, and look up her.

One sits astride her breathing in her mouth.

She isn't grateful; she has lost a shoe.

Purely aggrieved, she jumps up loud, insulting

And swears no man alive will throw her over.

She is so little; who can bear to doubt her.

She will be happy quickly.

She will learn.

Her obvious friend, a whore, is not surprised.

Cabiria yells in her gimcrack house.

She kisses her white hen for consolation.

How can it fail to happen.

Small, flat footed one, you will be taken.

You will sell your house too quickly.

The good man will promise he will marry.

He will not be a good man.

You will not be that girl again,

Black haired and eighteen, praying to Our Lady.

This time he will take everything,

But even he can't kill you. 
Blonde as a newborn, you will walk out crying,

Starting again, and waving buona sera

To the loved couples on their motorcycles,

To the parading children with their candles.

You will keep on going.

THE FEAR OF WOMEN, THE FEAR OF MEN

We come together strangers,

Fish and flower, flesh

Estranged from its

Dark prop, the other.

Come near the quick,

The drum the world falls in on.

Tell me what you see.

There is a ring of bone

And some hard moss.

I walk into a cave

I see no end to.

What do you see?

A rich, blind intruder,

Plainly damaging.

Quiet. Wait.

Your face is different.

Wait. Remember where we went today

And yesterday. Remember stories,

Jokes, our families.

Remember how we met.

I was afraid.

Remember? 